\title{
Eiléan Ní Chuilleanáin em tradução: três poemas sobre a linguagem
}

\author{
Luci Collin
}

A poeta irlandesa Eiléan Ní Chuilleanáin, nascida em Cork, em 1942, já publicou oito coletâneas de poemas e ocupa uma posição de destaque entre os grandes poetas irlandeses contemporâneos. Desde 1966 Ní Chuilleanáin leciona poesia renascentista e tradução no Trinity College, em Dublin. Além de poeta, tem diversas publicações como tradutora de irlandês, italiano, francês e romeno, e é uma das fundadoras da prestigiosa revista literária Cyphers, publicada desde 1975.

A poesia de Eiléan Ní Chuilleanáin, enigmática e lacunar, é iluminada pelo sólido background histórico da autora, por sua relação profunda com a linguagem e por sua íntima ligação com o catolicismo; temas como a família, o exílio, o corpo e a sensualidade, a voz da mulher, o sentido de lugar, o compromisso espiritual e os mistérios religiosos são recorrentes na obra de Ní Chuilleanáin.

Os poemas aqui traduzidos foram retirados, respectivamente, das seguintes coletâneas: The Magdalene Sermon (1989), The Brazen Serpent (1994) e The Girl Who Married the Reindeer (2001), todas publicadas pela Gallery Press, Dublin. 
Luci Collin. Eiléan Ní Chuilleanáin em tradução: três poemas sobre a linguagem

\section{Pygmalion's Image}

Not only her stone face, laid back staring in the ferns,

But everything the scoop of the valley contains begins to move

(And beyond the horizon the trucks beat the highway).

A tree inflates gently on the curve of the hill;

An insect crashes on the carved eyelid;

Grass blows westward from the roots,

As the wind knifes under her skin and ruffles it like a book.

The crisp hair is real, wriggling like snakes;

A rustle of veins, tick of blood in the throat;

The lines of the face tangle and catch, and

A green leaf of language comes twisting out of her mouth. 


\section{A imagem de Pigmaleão}

Não só o rosto pétreo dela, voltado para trás fitando as samambaias,

Mas tudo que a concavidade do vale contém começa a se mover

(E além do horizonte os caminhões cruzam a rodovia).

Uma árvore se infla delicada na curva da colina;

Um inseto colide contra a pálpebra esculpida;

O capim é soprado para o oeste desde as raízes,

Quando o vento corta a pele dela e a folheia como um livro.

O cabelo anelado é real, coleando como cobras;

Um sussurrar de veias, som de sangue na garganta;

As linhas do rosto se enredam e se compreendem, e

Uma folha nova de linguagem serpeia para fora de sua boca. 
Luci Collin. Eiléan Ní Chuilleanáin em tradução: três poemas sobre a linguagem

\section{Studying the Language}

On Sundays I watch the hermits coming out of their holes

Into the light. Their cliff is as full as a hive.

They crowd together on warm shoulders of rock

Where the sun has been shining, their joints crackle.

They begin to talk after a while.

I listen to their accents, they are not all

From this island, not all old,

Not even, I think, all masculine.

They are so wise, they do not pretend to see me.

They drink from the scattered pools of melted snow:

I walk right by them and drink when they have done.

I can see the marks of chains around their feet.

I call this my work, these decades and stations -

Because, without these, I would be a stranger here. 


\section{Estudando a Linguagem}

Aos domingos observo os ermitões saindo das tocas

Para a luz. Seu rochedo tão cheio quanto uma colméia.

Se reúnem sobre as mornas saliências da pedra

Onde bateu sol, suas juntas estralam.

Depois de um tempo, começam a conversar.

Ouço os sotaques, nem todos são

Desta ilha, nem todos são velhos,

Nem são, creio, todos machos.

São tão sábios, não fingem me ver.

Bebem das espelhadas poças de neve derretida:

Ando rente a eles e bebo quando já terminaram.

Vejo as marcas das correntes em volta de seus pés.

Chamo isso de meu ofício, estas dezenas do terço e essas estações da cruz Porque, sem elas, eu seria uma estranha aqui. 
Luci Collin. Eiléan Ní Chuilleanáin em tradução: três poemas sobre a linguagem

\section{The Horses of Meaning}

Let their hooves print the next bit of the story:

Release them, roughmaned

From the dark stable where

They rolled their dark eyes, shifted and stamped -

Let them out, and follow the sound, a regular clattering

On the cobbles of the yard, a pouring round the corner

Into the big field, a booming canter.

Now see where they rampage,

And whether they are suddenly halted

At the check of the line westward

Where the train passes at dawn -

If they stare at land that looks white in patches

As if it were frayed to bone (the growing light

Will detail as a thickening of small white flowers),

Can this be the end of their flight?

The wind combs their long tails, their stalls are empty. 


\section{Os Cavalos do Significado}

Deixe seus cascos imprimirem a próxima fração da história:

Liberte-os, ásperas crinas,

Do estábulo escuro onde

Remexiam os olhos negros, se agitavam e pateavam -

Deixe-os escapar e acompanhe o som, um tropel uniforme

Sobre as pedras do terreiro, uma torrente perto da curva

Em direção ao campo aberto, o estrondoso meio-galope.

Agora note onde se alvoroçam,

E se eles são refreados de repente

Na parada da linha a oeste

Onde o trem passa ao amanhecer -

Se olham fixo para a terra que parece torrões brancos

Como se estivesse desgastada até os ossos (a luz crescente

Dará detalhes como se uma profusão de florzinhas brancas),

É possível que este seja o fim de seu vôo?

O vento penteia seus longos rabos, os estábulos estão vazios. 